\title{
The effect of dietary oilseeds on physico-chemical characteristics, fatty acid profile and sensory aspects of meat of young zebu cattle
}

\author{
Samara MIYAKI ${ }^{1}$, Luís Carlos VINHAS ÍTAVO ${ }^{1}$, Marjorie TOLEDO DUARTE ${ }^{1}$, \\ Heitor Henrique COSTA VALERIANO ${ }^{1}$, Marília Williani FILGUEIRA PEREIRA ${ }^{1 \star}$ (D), \\ Thiago Luís ALVES CAMPOS DE ARAÚJO ${ }^{2}$, Camila Celeste BRANDÃO FERREIRA ÍTAVO ${ }^{1}$, \\ Rodrigo da COSTA GOMES ${ }^{3}$, Marina de NADAI BONIN ${ }^{1}$
}

\begin{abstract}
The aim of this study was to evaluate the influence of dietary oilseed grains on physico-chemical and sensory parameters of the meat of Nellore steers. The animals were distributed in a completely randomized design in four treatments that consisted of four diets: one without the addition of lipids (control diet) and others containing cottonseed, soybean, sunflower seed. The meat from animals fed with soybean scored highest for succulence and tenderness. The inclusion of oilseed grains modified the composition of fatty acids in the meat, but did not influence the lipid indexes or the cholesterol content in the meat. We suggest the inclusion of soybean in the diet of young cattle because increase the meat acceptability by consumers.
\end{abstract}

Keywords: sensory analysis; consumers; cottonseed; sunflower grain; soybean; tenderness.

Practical Application: Oilseeds influences meat quality and does not harm to human health lipid profile.

\section{Introduction}

Ruminant meat has been consumed for thousands of years and plays a vital role in global food security (Vahmani et al., 2020), despite this, there is defamatory information associated with this meat (Zeraatkar et al., 2019). Efforts have been made to relieve doubts about the nutritional role that ruminant meat plays in the human diet, and animal nutrition is a crucial factor (Guerreiro et al., 2020; Vahmani et al., 2020).

The food consumed by ruminant animals is important for the composition and quality of the meat, especially those foods that undergo changes by the ruminal microbiota, such as lipids. Using lipids as a nutrient source is a viable method of enriching meat products by rumen modulation. The feed consumed by the animals can alter the quality of the meat: fat is one of the feed components that most influences the sensory aspects of meat as it has an effect on the flavor, odor, succulence and tenderness (Fiorentini et al., 2012).

The supply of whole oilseeds grains to the animals is beneficial because they have a protective seed covering, enabling the lipids reach the gastrointestinal tract intact. The lipids are therefore absorbed in their original chemical composition, without causing toxicity to ruminal bacteria or impairing the absorption of nutrients and, consequently, affecting meat quality (Scollan et al., 2006). Oilseed grains used to feed ruminants include soybean, sunflower seeds and cottonseed. They are rich in oleic (C18:1 cis-9) and linoleic (C18:2 n-6) unsaturated fatty acids (Valadares et al., 2020), but when ingested as by-products of the agribusiness, such as oils, their consumption is associated with a decreased efficiency in fatty acid absorption and utilization (Costa et al., 2020). Thus, our hypothesis suggests an improvement in meat quality of young zebu cattle by introducing oilseed grains into diet. In this context, the aim of this study is to evaluate the effects of different oilseed grains on the physico-chemical characteristics, fatty acid profile and sensory aspects of the meat of young Nellore cattle.

\section{Material and methods}

\subsection{Study location and ethics}

This study was at the College of Veterinary Medicine and Animal Science of the Federal University of Mato Grosso do Sul. The experimental procedures were approved by the Ethics Committee on the Use of Animals (CEUA) (process number 654/2014) and the Human Research Ethics Committee (CEP) (process number 07651319.5.0000.0021, protocol number 329829) of this same institution.

\subsection{Animals and diet}

Twenty-four Nellore males, 24-months old, with an initial body weight of $311 \mathrm{~kg} \pm 17.98 \mathrm{~kg}$ were used. The treatments consisted of four experimental concentrate rations: one without oilseed grains (control) and three containing whole grains of one of the following oilseeds: cottonseed, soybean, and sunflower 
seeds (Figure 1), plus corn silage. The diets were formulated according to National Research Council (2000). For diets with grains, $150 \mathrm{~g} \mathrm{~kg}^{-1}$ of crude protein (CP) and $70 \mathrm{~g} \mathrm{~kg}^{-1}$ of ether extract (EE) in dry matter basis were determined. The addition of soy oil to the soybean-containing diet was necessary for it to reach the correct amount of EE (Table 1). The roughage to concentrate ratio was $40: 60$ and water was provided ad libitum throughout the experimental period. Food was supplied twice a day, adjusted daily, allowing $10 \%$ leftovers. The animals were confined in individual pens throughout the experimental period.

\subsection{Slaughter procedures}

The animals were slaughtered when they reached a weight of $518.0 \mathrm{~kg} \pm 22.9 \mathrm{~kg}$ in a commercial abattoir ( $85 \mathrm{~km}$ away), under the Brazilian Hygienic-Sanitary Inspection and Humane Slaughter (Brasil, 2017). The carcasses were identified and sawn along the spine, weighed to obtain the hot carcass weight (HCW) and cooled to $0^{\circ} \mathrm{C}$ to $2{ }^{\circ} \mathrm{C}$ for $24 \mathrm{~h}$. After cooling, the subcutaneous fat thickness (SFT) was measured in the region between the 12th and 13th ribs, using a digital caliper.

\section{Diets}

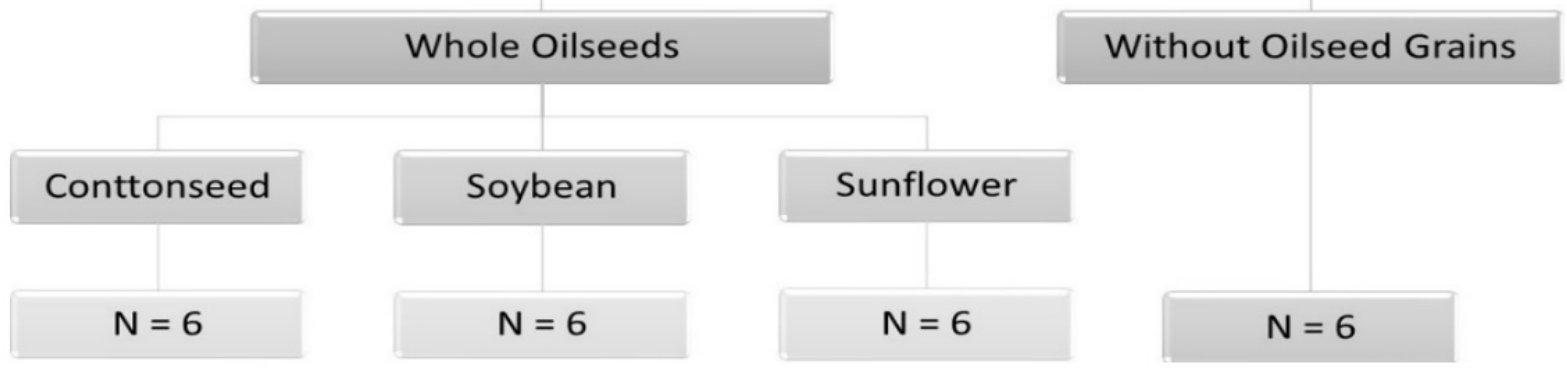

Figure 1. Experimental concentrates rations supplied to Nellore steers.

Table 1. Ingredients and chemical composition of experimental diets.

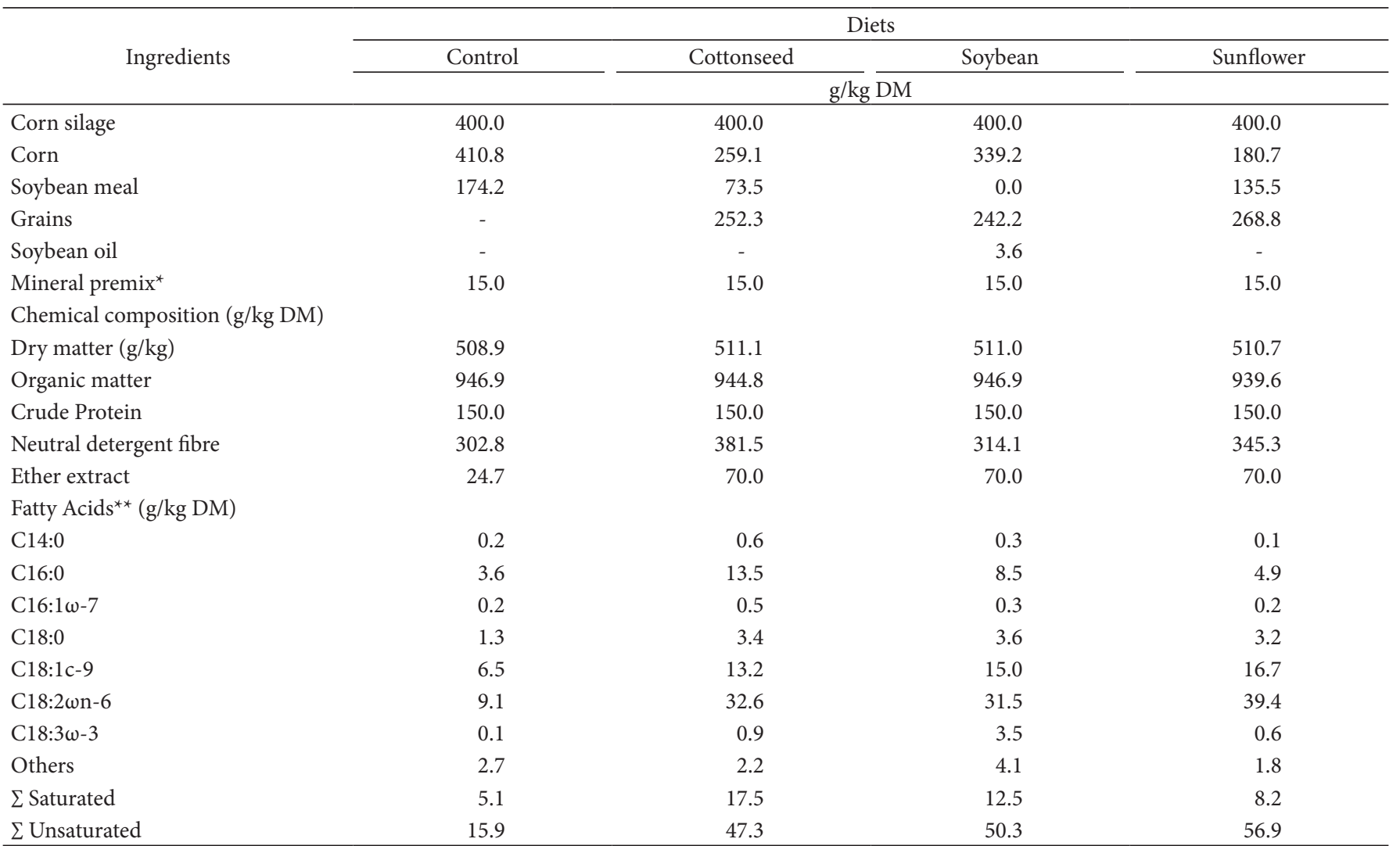

DM = Dry matter. ${ }^{*}$ Composition: sodium 100 g/kg; phosphor 88 g/kg; calcium 176 g/kg; magnesium 8000 mg $/ \mathrm{kg} ;$ sulfur 22 g/kg; zinc 3000 mg $/ \mathrm{kg} ;$ copper 1000 mg $/ \mathrm{kg} ;$ cobalt 80 mg $/ \mathrm{kg}$; iodine $60 \mathrm{mg} / \mathrm{kg}$; selenium $20 \mathrm{mg} / \mathrm{kg}$; fluorine $880 \mathrm{mg} / \mathrm{kg}$; ${ }^{* *}$ Values calculated from compilation of literature data (Zambiazi et al., 2007; Glasser et al., 2008; Oliveira et al., 2012, 2016) and Brazilian Cattle Feed Composition Table (Valadares Filho et al., 2020). 


\subsection{Sample collection}

Samples of the longissimus thoracis (LT) were taken from the left half carcass, between the 6th and 12th ribs for analysis of chemical composition, marbling, shear force (SF), dripping and cooking losses, sarcomere length (SL), myofibrillar fragmentation index (MFI), collagen, fat acid profile and sensorial consumers evaluation. The samples were vacuum packed and kept frozen $\left(-20^{\circ} \mathrm{C} \pm 2{ }^{\circ} \mathrm{C}\right)$ until the analyses.

\subsection{Meat quality evaluation}

\section{$p H$, color and marbling}

The $\mathrm{pH}$, color and marbling were evaluated between the 12th and 13th ribs, 20 min after LT exposure. The $\mathrm{pH}$ was measured using a pH meter (HI 99163, Hanna ${ }^{\circledR}$ instruments, São Paulo, Brazil) and the color with a portable spectrophotometer (Meter CR400, Konica ${ }^{\circledast}$ Minolta, Osaka, Japan), using the CIELAB color space. The values of Chroma $\left(\mathrm{C}^{\star}\right)$ and Hue $\left(\mathrm{H}^{\star}\right)$ were then calculated (Mac-Dougall, 1994). Marbling was scored according to American Meat Science Association (2001).

\section{Shear force, dripping and cooking losses}

The SF, dripping, and cooking losses were determined according to American Meat Science Association Standards (American Meat Science Association, 2016). The samples were thawed in a cold chamber at $2{ }^{\circ} \mathrm{C} \pm 2{ }^{\circ} \mathrm{C}$ for $24 \mathrm{~h}$ before the analysis procedures.

The samples were roasted in an electric oven at $163{ }^{\circ} \mathrm{C}$ (Layr, model Crystal, with upper and lower resistances, São Paulo, Brazil). The internal temperature was monitored with thermocouples (Taylor, model 1478-21, Ohio, USA), inserted in the geometric center of the samples, and removed from the oven when they reached $71^{\circ} \mathrm{C}$. After removal from the oven, they were immediately weighed to determination of the cooking losses.

Then, samples were stored in a refrigerator $\left(2\right.$ to $\left.5{ }^{\circ} \mathrm{C}\right)$ for $24 \mathrm{~h}$, prior to shear force analysis. Six sub samples $(1.27 \mathrm{~cm})$, in muscle fiber direction, were removed from each sample with a metal sinker adapted to an electrical drill.

The SF was determined in a texture analyzer (CT3 Warner Bratzler, Brookfield Engineering, USA) and the SF of the samples was calculated by the mean obtained from six sub-samples.

\section{Sarcomere length, myofibrillar fragmentation index and collagen}

The SL was assessed using an optical microscope with phase contrast, according to the methods modified by Heinemann et al. (2002). The MFI was calculated according to Culler et al. (1978).

The quantification of soluble and insoluble collagen was performed based on the quantification of hydroxyproline (Hill, 1966). The amount of collagen in the samples ( $\mathrm{g} 100 \mathrm{~g}^{-1}$ of fresh meat) was calculated according to the equations adapted by Cross et al. (1973).
Fatty acids and cholesterol

Lipid extraction was performed following the methods of Folch et al. (1957), using chloroform/methanol with the methyl ester of n-nonadecanoic acid, and an internal standard (1.5g C19:0 ME in $25 \mathrm{~mL}$ chloroform/methanol) for fatty acid normalization. The lipid extracts were converted to fatty acid methyl esters (FAME), using the methodology proposed by Nuernberg et al. (2007). For the gas chromatography (GC Thermo Trace GC Ultra, with column SP-2560, Merck/Sigma-Aldrich, Supelco ${ }^{\circledR}$, Bellefonte, PA, USA), the oven was set to the following conditions: $100^{\circ} \mathrm{C}$, 5 min hold, ramp $4{ }^{\circ} \mathrm{C} \mathrm{min}^{-1}$ to $220^{\circ} \mathrm{C}, 30$ min hold; post run: maximum ramp up to $100{ }^{\circ} \mathrm{C}, 5 \mathrm{~min}$ hold. Helio was used as a carrier gas, at a flow rate of $1.3 \mathrm{~mL} \mathrm{~min}^{-1}$. The split ratio was $1: 10$, and the injector and detector temperatures were $260^{\circ} \mathrm{C}$.

Concentrations of saturated fatty acids (SFAs), unsaturated fatty acids (UFAs), monounsaturated fatty acids (MFAs), polyunsaturated fatty acids (PUFAs), omega-6 ( $\omega 6)$ and omega-3 ( $\omega 3$ ) were calculated based on the fatty acid profile. The lipid quality indexes were determined using the sum of the desirable fatty acids (DFAs), as described in Rhee (2000). The thrombogenicity index (TI) and atherogenicity index (AI) (Ulbricht \& Southgate, 1991), and the ratio between the fatty acids hypocholesterolemic and hypercholesterolemic acids (h:H) (Santos-Silva et al. 2002) were also calculated. The Stearoyl CoA-Desaturase (SCD) activity in C:16 (SCD-16), C:17 (SCD-17) and C:18 (SCD-18) was determined according to Guerreiro et al. (2020).

Cholesterol quantification was performed according to the methodology described by Saldanha et al. (2004).

\section{Chemical composition}

The CP, DM and mineral matter (MM) were determined according to Association of Official Analytical Chemists (2000), methods number $976.05,930.15$ and 942.05 , respectively. The EE was quantified according to AOCS Am 5-04 (Association of Official Analytical Chemists, 2009).

\subsection{Sensory evaluation}

The sensory evaluation was carried out according to the methodology proposed by the (American Meat Science Association, 2016). The volunteer tasters (116) were randomly recruited. Attributes of the meat were scored according to the degree of liking or disliking, according to the methods in Instituto Adolfo Lutz (2008). The attributes of aroma, flavor, softness and succulence were evaluated with scores ranging from 1 to 7 points, with 1 meaning "very bad", 4 corresponding to "neither good / nor bad" and 7 being "excellent".

\subsection{Statistical analysis}

An analysis of variance (ANOVA) was performed, using the PROC GLM procedure in SAS.

The model used was according to the Equation 1:

$Y_{i}=\mu+T_{i}+\varepsilon_{i}$ 
where $\mathrm{Yi}$ is the dependent or response variable measured in the animal or experimental unit; $\mu$ is the population mean or global constant; Ti is the effect of the treatment; and $i$ and $\varepsilon i$ are unobserved random error.

The means were compared by the Tukey test, considering significant effects when $P \leq 0.05$.

\section{Results}

\subsection{Weight at slaughter and hot carcass weight}

The final body weight (final BW) of the animals differed between treatments $(P<0.05)$ (Table 2$)$. The animals fed with soybean showed the highest body weights, followed by those that consumed the control diet, cottonseed, and sunflower grains. The HCW was significantly higher in the animals fed with the control and soybean diets $(P<0.05)(267.83 \mathrm{~kg}$ and $267.0 \mathrm{~kg}$, respectively). The SFT was also higher in the control animals
$(4.75 \mathrm{~mm})$, and lower in animals fed with sunflower $(2.40 \mathrm{~mm})$ seed and cottonseed $(2.43 \mathrm{~mm})(P<0.05)$ (Table 2$)$.

\subsection{Meat quality}

The crude protein, moisture and mineral content of LT were not affected by the addition of oilseed grains in the diets $(P>0.05)$ (Table 3). The animals fed with sunflower grain had the lowest EE content in the meat $(P<0.05)$, while those fed with soybean, cottonseed and the control did not differ from each other $(P>0.05)$.

There was no significant difference in marbling, color, dripping and cooking losses, LS, MFI, total and insoluble collagen $(P>0.05)$ (Table 3$)$. The sunflower seed feed resulted in a higher carcass $\mathrm{pH}(\mathrm{NS}, P>0.05)$ (Table 3$)$.

The SF was higher in the meat of animals fed without oil seeds $(10.15 \mathrm{~kg})$, and lower in the meat of animals fed with

Table 2. Performance of feedlot cattle fed diets containing different oilseed grains.

\begin{tabular}{|c|c|c|c|c|c|c|}
\hline \multirow{2}{*}{ Item } & \multicolumn{4}{|c|}{ Diets } & \multirow{2}{*}{ SEM } & \multirow{2}{*}{$P$-value } \\
\hline & Control & Cottonseed & Soybean & Sunflower & & \\
\hline BW initial (kg) & 311.67 & 311 & 311.83 & 311.33 & 4.022 & 0.99987 \\
\hline BW final (kg) & $520.00^{\mathrm{ab}}$ & $522.67^{\mathrm{ab}}$ & $544.38^{\mathrm{a}}$ & $488.67^{\mathrm{b}}$ & 7.978 & 0.04594 \\
\hline $\mathrm{HCW}\left(\mathrm{kg} \operatorname{animal}^{-1}\right)$ & $267.83^{\mathrm{a}}$ & $252.83^{\mathrm{ab}}$ & $267.00^{\mathrm{a}}$ & $235.10^{\mathrm{b}}$ & 4.514 & 0.00631 \\
\hline $\mathrm{SFT}(\mathrm{mm})$ & $4.75^{\mathrm{a}}$ & $2.43^{\mathrm{b}}$ & $3.30^{\mathrm{ab}}$ & $2.40^{\mathrm{b}}$ & 0.295 & 0.0011 \\
\hline
\end{tabular}

Table 3. Effect of different oilseed grains inclusion on the physico-chemical characteristics and marbling of meat of the young zebu.

\begin{tabular}{|c|c|c|c|c|c|c|}
\hline \multirow{2}{*}{ Item } & \multicolumn{4}{|c|}{ Diets } & \multirow{2}{*}{ SEM } & \multirow{2}{*}{$P$-value } \\
\hline & Control & Cottonseed & Soybean & Sunflower & & \\
\hline Crude protein $(\%)$ & 21.48 & 20.94 & 21.22 & 20.93 & 0.15 & 0.4946 \\
\hline Moisture (\%) & 76.13 & 76.36 & 76.14 & 77.02 & 0.37 & 0.2149 \\
\hline Mineral matter (\%) & 1.45 & 1.47 & 1.45 & 1.46 & 0.02 & 0.9448 \\
\hline Ether extract (\%) & $0.94^{\mathrm{a}}$ & $1.23^{\mathrm{a}}$ & $1.19^{\mathrm{a}}$ & $0.59^{\mathrm{b}}$ & 0.06 & 0.0001 \\
\hline Marbling $^{* \star}$ & 5.17 & 4.83 & 4.83 & 3.83 & 0.26 & 0.2257 \\
\hline $\mathrm{L}^{*}$ & 36.61 & 35.26 & 37.19 & 35.39 & 0.42 & 0.1959 \\
\hline$a^{*}$ & 17.15 & 16.67 & 16.09 & 17.08 & 0.39 & 0.7196 \\
\hline $\mathrm{b}^{*}$ & 6.52 & 5.51 & 6.21 & 5.15 & 0.24 & 0.113 \\
\hline CHROMA & 18.39 & 17.64 & 17.45 & 17.89 & 0.39 & 0.8065 \\
\hline HUE & 20.93 & 17.97 & 21.18 & 16.21 & 1.27 & 0.0842 \\
\hline $\mathrm{pH}$ & $5.48^{\mathrm{b}}$ & $5.67^{\mathrm{ab}}$ & $5.64^{\mathrm{ab}}$ & $5.83^{\mathrm{a}}$ & 0.05 & 0.0233 \\
\hline Shear force (kg) & $10.15^{\mathrm{a}}$ & $8.12^{\mathrm{b}}$ & $8.31^{\mathrm{b}}$ & $7.56^{\mathrm{c}}$ & 3.08 & 0.0001 \\
\hline Dripping loss (\%) & 4.04 & 3.13 & 2.89 & 3.36 & 1.71 & 0.2337 \\
\hline Cooking loss (\%) & 32 & 31 & 26 & 23 & 0.02 & 0.0963 \\
\hline $\begin{array}{l}\text { Sarcomere length } \\
(\mu \mathrm{m})\end{array}$ & 1.8 & 1.81 & 1.84 & 1.81 & 0.14 & 0.1158 \\
\hline MFI & 65.39 & 62.78 & 63.05 & 63.27 & 0.43 & 0.0558 \\
\hline $\begin{array}{c}\text { Total collagen ( } \mathrm{g} \\
\left.100 \mathrm{~g}^{-1}\right)\end{array}$ & 0.06 & 0.06 & 0.06 & 0.06 & 0.0 & 0.6863 \\
\hline $\begin{array}{c}\text { Insoluble collagen } \\
(\%)\end{array}$ & 16.84 & 18.71 & 16.38 & 17.71 & 0.61 & 0.5198 \\
\hline
\end{tabular}

Diets: Control = without grains addition; Cottonseed = diet with cottonseed inclusion; Soybean = diet with soybean grains inclusion; Sunflower = diet with sunflower seed inclusion; SEM: standard error of the mean; MFI: myofibrillary fragmentation index; ${ }^{\mathrm{a}, \mathrm{b}}$ Means followed by different letters differ according to Tukey test $(P \leq 0.05) .{ }^{* *}$ Marbling 1 : trace e 18 : abundant. 
sunflower seed $(7.56 \mathrm{~kg})(P<0.05)$. Animals fed with soybeans and cottonseed showed intermediate and similar values (Table 3 ).

\subsection{Fatty acids and cholesterol}

The composition of fatty acids (FAs, mg $100 \mathrm{~g}^{-1}$ of muscle) the lipid index, activity of the stearoyl CoA desaturase enzyme and the cholesterol content are shown in Table 4.

There was no difference for SFAs C14:0, C15:0, C16:0, C17:0, C18:0, C21:0, C22:0 and C24:0 $(P>0.05)$. The inclusion of oilseed grains in the cattle's diet influenced the concentration of palmitic (C16:1) and oleic $(\mathrm{C} 18: 1$ cis-9) MFAs $(P<0.05)$. The lowest amounts of both acids were from the meat of animals fed with cottonseed, and the highest in the meat of animals fed the soybean and in the control.

Most PUFAs (mg $100 \mathrm{~g} \mathrm{~g}^{-1}$ of muscle) were lower by inclusion of the cottonseed [(C18:2 $\omega-6: 34.05),(\mathrm{C} 18: 3 \omega-3: 2.16)$ or soybean [(20:5: 2.37), (C22:2 $\omega-6: 0.51)](P<0.05)$. The concentration of docosahexaenoic acid (DHA, C22:6 $\omega-3)$ in the meat did not change when the cattle consumed oilseed grains $(P>0.05)$.

The concentration of SFAs, MFAs and PUFAs in beef was influenced by the oilseed grains intake: the highest concentrations of SFA and PUFA were observed in the meat from the control cattle $(P<0.05)$, while the lowest concentrations were observed in the meat of animals that ingested cottonseed and sunflower

Table 4. Fatty acid composition and cholesterol content (mg $100 \mathrm{~g}^{-1}$ of muscle) of meat of the cattle fed different oilseeds grains.

\begin{tabular}{|c|c|c|c|c|c|c|}
\hline \multirow{2}{*}{ Fatty acids (FA) } & \multicolumn{4}{|c|}{ Diets } & \multirow{2}{*}{ EPM } & \multirow{2}{*}{$P$-value } \\
\hline & Control & Cottonseed & Soybean & Sunflower & & \\
\hline C14:0 & 3.32 & 0.73 & 3.87 & 3.12 & 0.93 & 0.3212 \\
\hline C15:0 & 1.19 & 1.65 & 0.82 & 1.24 & 0.12 & 0.2070 \\
\hline C16:0 & 136.99 & 83.55 & 111.09 & 79.63 & 8.50 & 0.05 \\
\hline C17:0 & 6.86 & 5.79 & 6.32 & 6.69 & 0.53 & 0.9058 \\
\hline C18:0 & 121.71 & 85.47 & 88.01 & 83.56 & 6.79 & 0.1402 \\
\hline C21:0 & 2.86 & 1.16 & 2.84 & 2.89 & 0.34 & 0.7551 \\
\hline C22:0 & 2.33 & 1.70 & 1.92 & 2.57 & 0.13 & 0.0901 \\
\hline C24:0 & 12.66 & 10.31 & 8.70 & 11.07 & 0.79 & 0.3592 \\
\hline C16:1 & $10.94^{\mathrm{a}}$ & $4.09^{b}$ & $11.49^{\mathrm{a}}$ & $6.08^{\mathrm{ab}}$ & 1.10 & 0.0123 \\
\hline C17:1cis-9 & $2.76^{\mathrm{a}}$ & $1.18^{\mathrm{b}}$ & $2.78^{\mathrm{a}}$ & $1.77^{\mathrm{ab}}$ & 0.23 & 0.0273 \\
\hline C18:1trans -10 & 12.64 & 7.21 & 8.52 & 7.82 & 0.87 & 0.0618 \\
\hline C18:1trans-11 & 4.71 & 6.60 & 5.98 & 5.52 & 0.70 & 0.8084 \\
\hline C18:1cis-9 & $108.06^{\mathrm{a}}$ & $50.67^{c}$ & $91.45^{\mathrm{ab}}$ & $61.89^{b c}$ & 6.96 & 0.0005 \\
\hline 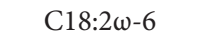 & $62.11^{\mathrm{a}}$ & $34.05^{\mathrm{b}}$ & $46.64^{\mathrm{ab}}$ & $54.24^{\mathrm{ab}}$ & 3.96 & 0.0312 \\
\hline $\mathrm{C} 18: 3 \omega-3$ & $4.24^{\mathrm{a}}$ & $2.16^{\mathrm{b}}$ & $3.31^{\mathrm{ab}}$ & $3.55^{\mathrm{ab}}$ & 0.25 & 0.0070 \\
\hline$C 20: 3 \omega-6$ & 4.78 & 3.08 & 3.78 & 4.87 & 0.33 & 0.1972 \\
\hline C20:5 & $3.86^{\mathrm{ab}}$ & - & $2.37^{b}$ & $4.24^{\mathrm{a}}$ & 0.30 & 0.0129 \\
\hline$C 22: 2 \omega-6$ & $1.26^{\mathrm{a}}$ & $0.89^{\mathrm{ab}}$ & $0.51^{\mathrm{b}}$ & $1.39^{\mathrm{a}}$ & 0.13 & 0.0170 \\
\hline$C 22: 6 \omega-3$ & 1.21 & - & 0.72 & 1.34 & 0.12 & 0.0796 \\
\hline$\sum$ PUFA & $72.98^{\mathrm{a}}$ & $38.06^{\mathrm{b}}$ & $55.28^{\mathrm{ab}}$ & $65.31^{\mathrm{ab}}$ & 4.68 & 0.0151 \\
\hline$\sum$ MUFA & $142.84^{\mathrm{a}}$ & $68.06^{\mathrm{b}}$ & $121.35^{\mathrm{ab}}$ & $83.02^{\mathrm{b}}$ & 9.70 & 0.0030 \\
\hline$\sum$ DFA & $308.96^{\mathrm{a}}$ & $187.73^{b}$ & $217.50^{\mathrm{ab}}$ & $191.47^{b}$ & 16.01 & 0.0084 \\
\hline Desirable FA & $348.05^{\mathrm{a}}$ & $191.58^{\mathrm{b}}$ & $254.95^{\mathrm{ab}}$ & $231.89^{\mathrm{ab}}$ & 18.35 & 0.0027 \\
\hline Omega 6 & $67.73^{\mathrm{ab}}$ & $36.26^{b}$ & $51.39^{\mathrm{ab}}$ & $60.47^{\mathrm{ab}}$ & 4.36 & 0.0236 \\
\hline Omega 3 & $5.25^{\mathrm{a}}$ & $2.16^{\mathrm{c}}$ & $3.89^{\mathrm{b}}$ & $4.84^{\mathrm{ab}}$ & 0.33 & $<.0001$ \\
\hline$\omega-6: \omega-3$ & 12.87 & 15.49 & 13.08 & 12.50 & 0.51 & 0.2968 \\
\hline $\mathrm{TI}$ & 2.16 & 2.09 & 2.09 & 1.94 & 0.04 & 0.0637 \\
\hline $\mathrm{AI}$ & 0.72 & 0.76 & 0.74 & 0.61 & 0.03 & 0.2558 \\
\hline h:H & 1.18 & 1.07 & 1.17 & 1.44 & 0.05 & 0.0709 \\
\hline SCD-16 & $7.65^{\mathrm{a}}$ & $4.40^{\mathrm{b}}$ & $9.34^{\mathrm{a}}$ & $7.89^{a}$ & 0.56 & 0.0041 \\
\hline SCD-17 & $27.29^{\mathrm{ab}}$ & $18.12^{\mathrm{b}}$ & $31.30^{\mathrm{a}}$ & $20.54^{\mathrm{ab}}$ & 1.79 & 0.0346 \\
\hline SCD-18 & 42.81 & 38.94 & 44.43 & 43.65 & 1.014 & 0.2257 \\
\hline Cholesterol & 54.56 & 46.33 & 47.19 & 44.07 & 1.991 & 0.2387 \\
\hline
\end{tabular}

Diets: Control = without grains addition; Cottonseed = diet with cottonseed inclusion; Soybean = diet with soybean grains inclusion; Sunflower = diet with sunflower seed inclusion;

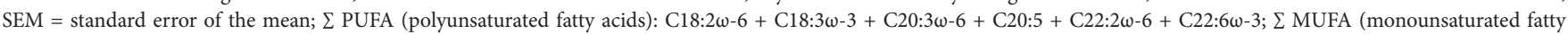
acids): C16:1 + C17:1cis-9 + C18:1trans-10 + C 8:1trans-11 + C18:1cis-9; $\Sigma$ SFA (saturated fatty acids): C14:0 + C15:0 + C16:0 + C17:0 + C18:0 + C21:0 + C22:0 + C24:0; Desirable

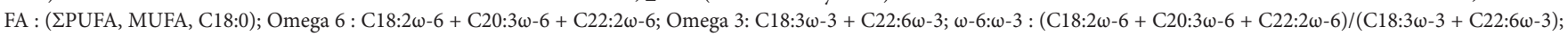
TI (thrombogenicity index): [( $\Sigma \mathrm{C} 14: 0, \mathrm{C} 16: 0, \mathrm{C} 18: 0) / \Sigma(0.5 \mathrm{x} \Sigma \mathrm{MUFA}),(0.5 \mathrm{x} \Sigma \omega-6),(3 \mathrm{x} \Sigma \omega-3),(\Sigma \omega-3 / \Sigma \omega-6)]$; AI (atherogenicity index): $\{[(4 \mathrm{xC} 14: 0), \mathrm{C} 16: 0] /[(\Sigma \omega-3, \omega-6)+(\mathrm{C} 18: 1 \mathrm{c}-9)$ $+(\Sigma$ others MUFA)]\}; h:H (hypocholesterolemic:hypercholesterolemic index): ( $\Sigma$ C18:1c-9, C18:2c-9, C18:3 $\omega-6$, C20:5 / $\Sigma$ C14:0, C16:0); SCD-16 (stearoyl CoA desaturase in C16:0): $\left(\mathrm{c} 9-16: 1 /(\mathrm{c} 9-16: 1+16: 0)^{*} 100\right)$; SCD-17 (stearoyl CoA desaturase in C17:0) : (c9-17:1/(c9-17:1 + 17:0)*100); SCD-18 (stearoyl CoA desaturase in C18:0): $\left(\mathrm{c} 9-18: 1 /(\mathrm{c} 9-18: 1+18: 0)^{\star} 100\right)$; a,b,c Means followed by different letters differ according to Tukey test $(P \leq 0.05)$. 
seed. The amount of SFA and PUFA in the meat of animals that consumed soybean was not significantly different from the other oilseed diets.

The $\omega-3$ and $\omega-6$ concentrations were decreased by the inclusion of cottonseed on the diet $(P<0.05)$, however, the $\omega 6 / \omega 3$ ratio was not affected by diet. The TI, AI, and h: $\mathrm{H}$ did not change when the cattle were fed different oilseeds $(P>0.05)$. With regards to enzymatic activity in the tissue, only stearoyl CoA desaturase in C18:0 (SCD-18) was not influenced by the dietary inclusion of grains $(P>0.05)$. The stearoyl CoA desaturase at C16:0 (SCD-16) and C17:0 (SCD-17) was metabolically less active $(P<0.05)$ in the tissue of animals that consumed cottonseed (4.40 and $18.12 \%$, respectively).

The amount of cholesterol (mg $100 \mathrm{~g}^{-1}$ of muscle) was similar in meat from all the animals, regardless of whether they had consumed oilseeds or not $(P>0.05)$.

\subsection{Sensory evaluation}

Only the aroma did not differ in the meat of the animals fed with oilseeds $(P>0.05)$ (Table 5). The flavor of meat from animals fed a grain-free (control) and soybean diet scored more highly (4.44 and 5.20, respectively) on the evaluation than those fed with sunflower seed (4.38) and cottonseed (4.28). The meat of animals fed with soybean was scored as more juice (5.67) and tender $(5.84)(P<0.05)$, while the animals fed with sunflower seeds scored the lowest for these attributes (juiciness: 3.99 and tenderness: 3.78).

\section{Discussion}

\subsection{Performance}

In our study, cattle that consumed oilseed grains obtained higher live weights at the end of the experimental period, as well as higher HCW. These differences can be explained by the amount of grains ingested, as well as the possible selection of grains by animals, as well as the higher energy intake due to the greater amount of EE provided in diets containing oilseeds. This possibly resulted in changes in rumen fermentation and in the cellulolytic and methanogenic bacteria activities, caused by the high-energy content and the greater amount of unsaturated fatty acids present in grain diets.

Interestingly, we observed that the greatest SFT was obtained by animals fed without oilseed grains. These results can be explained, in part, by the decreased efficiency in absorption and the corresponding reduction in fat deposition caused by the physical barrier that the grains naturally possess. In addition, we believe that the short period of feedlot and the fact that the animals are not castrated, influencing growth rate and body composition, may have contributed. The mean SFT value obtained of animals in our study $(3.22 \mathrm{~mm})$ is well below the value of $7.38 \mathrm{~mm}$ for Zebu steers fed with different oils either protected or unprotected from rumen degradation obtained by Oliveira et al. (2012).

\subsection{Chemical composition and marbling}

We did not observe any variation in the meat composition between diets, except for the EE being lower in the meat of animals fed with sunflower seed. This may be related to the lower HCW and the smaller SFT showed by the animals fed with sunflower, as the oilseed grain diets had the same EE amount, and the animals were the same age.

We observed that marbling values of the meat did not differ between animals fed different diets. This can be explained by the effects observed in SFT and HCW between treatments: there is a correlation between marbling and increased slaughter weight, which is related to the thickness of subcutaneous fat and the fat content of the carcass (Costa et al., 2002). Furthermore, the deposit of intramuscular fat occurs only after a certain period of the during feedlot, when the animal reaches its genetic potential and maturity (Arboitte et al., 2004). It is therefore likely that the animals in the present study did not remain in the feedlot long enough to deposit intramuscular fat from their diet.

\subsection{Physico-chemical characteristics of meat}

We observed that the physico-chemical evaluations of the meat were less sensitive than the sensory evaluations in detecting differences in the meat quality. In the firsts, there were no statistical differences between most of the studied variables; however, in the seconds, only differences in the meat aroma of animals fed different diets was not perceived by consumers. This because, in the sensory evaluations the tasters use smell, taste and tactile sensations of the tongue to assign scores related to the tenderness, juiciness, aroma, and flavor, and it no occurs in the physico-chemical evaluations. Therefore, it is essential that evaluations by both techniques are employed to detect sensitive changes in meat quality, when supplying different diets to animals.

The diets also influenced the meat $\mathrm{pH}$. The final $\mathrm{pH}$ of the meat depends on the lactic acid accumulation in the muscle, as a result of the production of adenosine triphosphate, using glycogen as a glucose source. In general, cattle fed grain-based

Table 5. Sensory characteristics of meat from cattle fed with oilseeds.

\begin{tabular}{|c|c|c|c|c|c|c|}
\hline & \multicolumn{4}{|c|}{ Diets } & \multirow{2}{*}{ SEM } & \multirow{2}{*}{$P$-value } \\
\hline & Control & Cottonseed & Soybean & Sunflower & & \\
\hline Flavor & $4.44^{\mathrm{a}}$ & $4.28^{\mathrm{b}}$ & $5.20^{\mathrm{a}}$ & $4.38^{\mathrm{b}}$ & 0.11 & $<0.001$ \\
\hline Aroma & 4.90 & 4.65 & 4.87 & 4.59 & 0.09 & 0.039 \\
\hline Juiceness & $4.92^{\mathrm{b}}$ & $4.57^{\mathrm{b}}$ & $5.67^{\mathrm{a}}$ & $3.99^{c}$ & 0.1 & $<0.001$ \\
\hline Tenderness & $4.92^{\mathrm{b}}$ & $4.75^{\mathrm{b}}$ & $5.84^{\mathrm{a}}$ & $3.78^{\mathrm{c}}$ & 0.12 & $<0.001$ \\
\hline
\end{tabular}

Diets: Control = without grains addition; Cottonseed = diet with cottonseed inclusion; Soybean = diet with soybean grains inclusion; Sunflower = diet with sunflower seed inclusion; SEM = standard error of the mean; ${ }^{\mathrm{a}, \mathrm{b}, \mathrm{c}}$ Means followed by different letters differ according to Tukey test $(P \leq 0.05)$. Notes: 1 : very bad and 7 : great. 
diets have greater availability of glycogen at the time of slaughter and a lower final $\mathrm{pH}$ of the meat. This is due to the optimization of starch fermentation for the production of propionate (glycogen precursor) and increased digestion and absorption of glucose through the small intestine (Park et al., 2018). In this way, the oilseeds composition, as well as their metabolism, may have resulted in different energy sources available for the muscle tissue that, after slaughter, resulted in different glycolysis rates and therefore different meat $\mathrm{pH}$ values.

The SF values were above $7.5 \mathrm{~kg}$ in this study: this is high compared to the average values for Taurine breeds $(4.3 \mathrm{~kg})$ (Bos taurus taurus) (McClure et al., 2012), but close to the average values reported for Zebu animals (9.0 kg) (Crouse et al., 1989). The lower tenderness of the meat of the zebu cattle can also explained by the positive correlation between the age at slaughter of the animals and the number of thermostable cross-links of the collagen of the muscles, favoring the hardness of the meat. As well as by the lower subcutaneous fat deposition in the carcass which favors faster cooling of muscle masses, causing shortening of sarcomeres (contractile muscle units) and, consequently, the hardening of meat (Alves et al., 2005). Particularities of the Nellore breed that may justify the high shear value are the high calpastatin activity and collagen solubility (Oliveira et al., 2012). However, in this study young animals (24 months) were used, therefore the influence of connective tissue on tenderness may have been slight, as only about $17 \%$ of the total collagen was present in the insoluble form in the animal meat.

In this study, it is likely that the meat tenderness, postmortem, is due to changes in myofibrillar proteins, rather than changes in connective tissue. Meat tenderness is influenced by the content and structure of the connective tissue and the compactness of the sarcomeres (Alves et al., 2005). Other myofibrillar components, such as the degree of sarcomeres contraction and the myofibrils fragmentation, could have influenced the SF of the meat. In the present study, the MFI values were close to those of meats considered soft (60.44) (Culler et al., 1978), with values above 60 , and did not differ between treatments.

\subsection{Sensory evaluation}

Although there were no significant differences in most physical and chemical parameters, consumers identified sensory changes between the different dietary treatments. Unlike analytical laboratory methods, in sensory evaluations it is possible to determine the quality by integrating human perceptions of smell, taste and tactile sensations of the tongue and mouth, translating this into notes about the flavor, aroma, succulence and tenderness of the meat (Instituto Adolfo Lutz, 2008). These sensory changes can be attributed to the variations in the amount of intramuscular fat, $\mathrm{pH}$ and $\mathrm{SF}$ values between treatments, although the magnitude of the sensory changes that occur are not always reflected by the physico-chemical evaluations.

The juiciness of meat comes from the water being released at the beginning of chewing, and the fat that stimulates salivation. The effect on tenderness of marbling fat is due to the decrease in meat density, with less tension between the layers of connective tissue providing greater "lubrication" of the protein by lipids and increasing the fat's ability to heighten salivation (Alves et al., 2005). Intramuscular fat may be related to the flavor, tenderness, and succulence of the meat: in our study, the addition of oilseeds in the diets changed the amount (and possibly the composition) of intramuscular fat. Not always in the same proportion, greater amounts of intramuscular fat (Cottonseed: 1.23\%; Soybean: 1.19\%; Control: 0.94\%), presented the highest succulence notes (Soybean: 5.67; Control: 4.92; Cottonseed: 4.57) and tenderness (Soybean: 5.84; Control: 4.92; Cottonseed: 4.75).

The lowest-scoring flavor notes were associated with the sunflower grain and cottonseed and may be related to volatile compounds released during cooking. According to Martins et al. (2018), 90\% of the volatile compounds related to flavor come from the oxidation of UFAs, released during the meat heating. In addition, compounds such as gossypol in cottonseed, and chlorogenic acid in sunflower, may have been accentuated during cooking, resulting in flavor changes and greater rejection by consumers. According to Paim et al. (2019), the gossypol effects on longissimus proteins seem to promote a low glycogen stock associated with a high fast-muscle function, promoting fast glycogen consumption with fast $\mathrm{pH}$ decline during the first step of conversion of muscle to meat. This can lead to high $\mathrm{pH}$ at the end of the process due to the low glycogen stock at the beginning. In this sense, some problems can arise in meat processing and storage when the meat comes from mainly whole cottonseed-fed animals. These problems could be biologically related to alterations in meat flavor. In the same way, the chlorogenic acid interaction with phenolic compost can affect aspects such as protein digestibility and its functionalities, modifying the useful life of the product and its stability, or even altering its organoleptic properties.

It is important to note that the coincidence of the best perceptions of flavor associated with the meat of animals fed with soybean and without grains may be due to the fact that in the latter, soybean meal was used and may have contributed to the flavor most appreciated by consumers.

The variations in $\mathrm{pH}$ may also have contributed to the differences in the perception of juiciness and tenderness, as it directly influences the water holding capacity, and consequently the succulence of the meat. The water lost during storage is mainly from extracellular water and water that is held in muscle by being entrapped by the structural features of the muscle cell (entrapped water), the latter being most vulnerable to storage when the $\mathrm{pH}$ is between 5.0 and 5.5. Meats with a $\mathrm{pH}$ close to these values therefore tend to lose more fluids when stored and cooked, as well as releasing more fluids when subjected to forces, such as those exerted by the teeth during chewing. In this study, the meats that scored most highly for succulence were those with a $\mathrm{pH}$ of between 5.48 and 5.6, possibly due to the fact that they are close to the $\mathrm{pH}$ range more susceptible to fluid losses, resulting in greater release of liquid during chewing.

The SF, SL and the MFI results were in contrast to the tenderness results. This is because the former variables represent only the myofibrillar portion of the meat, and are therefore not a complete representation of the consumer's perception. During chewing, there is an interaction between sensory and tactile perceptions that, together, can alter the sensitivity of each of 
the evaluated characteristics. This highlights the importance of sensory tests to assess the effect of diet on the quality of meat, as perceived by the consumer.

\subsection{Fatty acids}

The cattle fed with cottonseed had a lower PUFA concentration (mg $100 \mathrm{~g}^{-1}$ of muscle) compared to those fed a control diet, mainly due to the concentrations of linoleic acid (LA, 18:2n-6) and $\alpha$-linolenic acid (ALA, 18:3n-3). Although the cotton grain contains a considerable amount of LA and ALA (Table 1), they were not deposited in a higher concentration in the animal's meat. The process of ruminal biohydrogenation converts these fatty acids into stearic acid, or intermediates (Bessa et al., 2015); however, the concentration of possible biohydrogenation intermediates (C18:1-t11 and t-10), as well as the stearic acid concentration, were not higher in the meat of these animals. Additionally, ALA is the precursor to long-chain n-3 fatty acids, including eicosapentaenoic acid (EPA, 20:5 n-3), docosapentaenoic acid (DPA, 22:5 n-3) and docosahexaenoic acid (DHA, 22:6 n-3). However, several biological factors are involved in PUFA n-3 synthesis from ALA (Vahmani et al., 2020), and this process is slow and inefficient compared to the direct absorption of n-3 (Emken et al., 1990). Therefore, to promote greater PUFA n-3 deposition, it is necessary to combine the supply of ALA with sources of EPA and DHA (Vahmani et al., 2020). This may explain the inconsistent results between ALA and EPA concentrations in the meat of the animals in our study.

The MFA concentration in the meat of animals fed with cottonseed was lower in the control group, and those fed soybean. This reflects the lower activity of stearoyl CoA Desaturase in C17:0 and C16:0 (SCD-17 and SCD-16) in the muscle of these animals. SCD activity is related to the level of fat deposition (Bessa et al., 2015), however, in our study we observed a contradictory relationship between the fat concentration and SCD-17 and SCD-16 activity in the meat of animals fed with cottonseed since high EE did not reflect greater SCD activity.

The SFA concentration was lower in the meat of animals fed with cottonseed, compared to those fed the control diet. However, the desirable FAs index showed the same behavior as SFA sum. We anticipated that the desirable FAs would be found in higher concentrations when the animals had consumed greater amounts of PUFA, however the high amount of PUFA in the control group may have contributed to this result.

The lower concentration of SFA in the beef of cottonseed fed animals could represent a benefit to the lipid profile of the meat. On the other hand, this meat had less DFA index compared to beef of control diet animals, because this one showed higher concentration of PUFA, since DFA index is calculated according to concentration of PUFA, MUFA and C18:0 (Rhee, 2000).

Meat cholesterol concentration was not influenced by animal diets, so that it may represent a benefit relationship to meat quality on human health perspective. It could be explained, in part, by the similar SFA concentrations that have low or no hypercholesterolemic activity, such as palmitic acid (C16:0) and stearic acid (C18:0), respectively. These SFAs represent more than $50 \%$ of the total lipid composition in the meat of animals (Hwang \& Joo, 2017).

The lipid quality indexes showed that no meat had a less favorable to human health lipid profile, regardless of the consumption of oilseeds or not. The similarity between the $\mathrm{AI}$, the $\mathrm{h}: \mathrm{H}$ ratio and the $\omega-6 / \omega-3$ ratio indicates a similar fat quality between meats. A balanced $\omega-6 / \omega-3$ ratio is particularly beneficial in the meat of ruminants (Martins et al., 2018) and is achieved by regulating the daily intake of foods that are n- 6 and n-3 fatty acid sources, both of which are important for health human. No limit for this proportion, if $\omega-6$ and $\omega-3$ intake is within the appropriate range for human diets. However, this varies according to some authors and countries. In our study, the $n-6 / n-3$ ratios varied from 12:1 to $15: 1$ between the meat of animals fed with a grain-free diet and the meat of animals fed with cottonseed, respectively.

\section{Conclusion}

The inclusion of oilseed grains in the bovine diet influences meat quality. Soybean improves the sensory aspects of the meat of young cattle, increasing the meat acceptability by consumers and does not harm the physico-chemical aspects. We recommend the inclusion of sunflower and soybean grains to feed young cattle because they do not negatively influence the composition of fatty acids in meat.

\section{Acknowledgements}

We thank the Coordenação de Aperfeiçoamento de Pessoal de Nível Superior (CAPES) [financial code 001], Conselho Nacional de Desenvolvimento Científico e Tecnológico (CNPq) and Fundação de Apoio ao Desenvolvimento do Ensino, Ciência e Tecnologia do Estado de Mato Grosso do Sul (FUNDECT).

\section{References}

Alves, D. D., Goes, R. H. T. B., \& Mancio, A. B. (2005). Maciez da carne bovina. Ciência Animal Brasileira, 6(3), 135-149.

American Meat Science Association - AMSA. (2001). Handbook Meat Evaluation. Retrieved from https://meatscience.org/publicationsresources/printed-publications

American Meat Science Association - AMSA. (2016). Handbook Meat Evaluation. Retrieved from https://meatscience.org/publicationsresources/printed-publications

Arboitte, M. Z., Restle, J., Alves Filho, D. C., Brondani, I. L., Silva, J. H. S., Nörnberg, J. L., \& Kuss, F. (2004). Desempenho em confinamento de novilhos $5 / 8$ Nelore - $3 / 8$ Charolês abatidos em diferentes estádios de desenvolvimento. Revista Brasileira de Zootecnia, 33(4), 947-958. https://doi.org/10.1590/S1516-35982004000400015.

Association of Official Analytical Chemists - AOAC. (2000). Official methods of analysis Moisture content. 930.15. Protein content in meat. 976.05. Nitrogen in Meat Kjeldahl. Mineral matter. 942.05 (13th ed., Method. 928.08). Gaithersburgh: AOAC.

Association of Official Analytical Chemists - AOAC. (2009). Methods and recommended pratices of the AOCS. Ether Extract. Am 5-04. American Oil Chemist's Society. Gaithersburgh: AOAC.

Bessa, R. J. B., Alves, S. P., \& Santos-Silva, J. (2015). Constraints and potentials for the nutritional modulation of the fatty acid composition 
of ruminant meat. European Journal of Lipid Science and Technology, 117(9), 1325-1344. http://dx.doi.org/10.1002/ejlt.201400468.

Brasil, Ministério da Agricultura. (2017). Inspeção Industrial e Sanitária de Carnes e Derivados. Regulamento da Inspeção Industrial e Sanitária de Produtos de Origem Animal - RIISPOA.

Costa, E. C. C., Restle, J., Brondani, I. L., Perottoni, J., Faturi, C., \& Menezes, L. F. G. (2002). Composição física da carcaça, qualidade da carne e conteúdo de colesterol no músculo Longissimus dorsi de Novilhos Red Angus superprecoces, terminados em confinamento e abatidos com diferentes pesos. Revista Brasileira de Zootecnia, 31(Suppl. 1), 417-428. http://dx.doi.org/10.1590/S1516-35982002000200017.

Costa, F. S., Cabral, A. R., Silva, S. L., Silva, M. A. I., Henrique, W., Mazalli, M. R., Baldi, F. S., Mueller, L. F., Ferrinho, A. M., Corte, R. R. P. S., \& Pereira, A. S. C. (2020). Effects of n-3 and n- 6 feeding sources on the quality and lipid oxidation of meat from feedlotfinished Bos indicus steers. Meat Science, 161, 107966. http://dx.doi. org/10.1016/j.meatsci.2019.107966. PMid:31689663.

Cross, H. R., Carpenter, Z. L., \& Smith, G. C. (1973). Effects of intramuscular collagen and elastin on bovine muscle tenderness. Journal of Food Science, 38(6), 998-1003. http://dx.doi.org/10.1111/j.1365-2621.1973. tb02133.x.

Crouse, J. D., Cundiff, L. V., Koch, R. M., Koohmaraie, M., \& Seideman, S. C. (1989). Comparisons of Bos indicus and Bos taurus inheritance for carcass beef characteristics and meat palatability. Journal of Animal Science, 67(10), 2661-2668. http://dx.doi.org/10.2527/ jas1989.67102661x.

Culler, R. D., Parrish, F. C. Jr, Smith, G. G., \& Cross, H. R. (1978). Relationship of myofibril fragmentation index to certain chemical, physical and sensory characteristics of bovine Longissimus muscle. Journal of Food Science, 43(4), 1177-1180. http://dx.doi. org/10.1111/j.1365-2621.1978.tb15263.x.

Emken, E. A., Adlof, R. O., Rakoff, H., Rohwedder, W. K., \& Gulley, R. M. (1990). Metabolism in vivo of deuterium-labelled linolenic and linoleic acids in humans. Biochemical Society Transactions, 18(5), 766-769. http://dx.doi.org/10.1042/bst0180766. PMid:2083671.

Fiorentini, G., Berchielli, T. T., Santana, M. C. A., Dian, P. H. M., Reis, R. A., Sampaio, A. A. M., \& Biehl, M. V. (2012). Qualitative characteristics of meat from confined crossbred heifers fed with lipid sources. Scientia Agrícola, 69(5), 336-344. http://dx.doi.org/10.1590/ S0103-90162012000500008.

Folch, J., Lees, M., \& Stanley, G. H. S. (1957). A simple method for the isolation and purification of total lipides from animal tissue. The Journal of Biological Chemistry, 226(1), 497-509. http://dx.doi. org/10.1016/S0021-9258(18)64849-5. PMid:13428781.

Glasser, F., Ferlay, A., \& Chilliard, Y. (2008). Oilseed lipid supplements and fatty acid composition of cow milk: a meta-analysis. Journal of Dairy Science, 91(12), 4687-4703. http://dx.doi.org/10.3168/ jds.2008-0987. PMid:19038946.

Guerreiro, O., Alves, S. P., Soldado, D., Cachucho, L., Almeida, J., Francisco, A., Santos-Silva, J., Bessa, R. J. B., \& Jerónimo, E. (2020). Inclusion of the aerial part and condensed tannin extract from Cistus ladanifer L. in lamb diets - effects on growth performance, carcass and meat quality and fatty acid composition of intramuscular and subcutaneous fat. Meat Science, 160, 107945. http://dx.doi. org/10.1016/j.meatsci.2019.107945. PMid:31627117.

Heinemann, R. J. B., Pinto, M. F., Ponsano, E. H. G., \& Perri, S. H. V. (2002). Métodos simples para estimar encurtamento pelo frio em carne bovina. Ciência Rural, 32(2), 335-339. http://dx.doi.org/10.1590/ S0103-84782002000200025.
Hill, F. (1966). The solubility of intramuscular collagen in meat from animals of various ages. Journal of Food Science, 31(2), 379-383. http://dx.doi.org/10.1111/j.1365-2621.1966.tb00472.x.

Hwang, Y. H., \& Joo, S. T. (2017). Fatty acid profiles, meat quality and sensory palatability of grainfed and grass-fed beef from Hanwoo, American and Australian crossbred cattle. Korean Journal for Food Science of Animal Resources, 37(2), 153-161. http://dx.doi.org/10.5851/ kosfa.2017.37.2.153. PMid:28515638.

Instituto Adolfo Lutz - IAL. (2008). Métodos físico-químicos para análise de alimentos (4 ed.). São Paulo: Instituto Adolfo Lutz.

MacDougall, D. B. (1994). Colour of meat. In A. M. Pearson \& T. R. Dutson (Eds.), Quality attributes and their measurement in meat, poultry and fish products (Chap. 3, pp. 79-93). Boston: Springer. http://dx.doi.org/10.1007/978-1-4615-2167-9_3.

Martins, T. S., Lemos, M. V. A., Mueller, L. F., Baldi, F., Amorim, T. R., Ferrinho, A. M., Muñoz, J. A., Fuzikawa, I. H. S., Moura, G. V., Gemelli, J. L., \& Pereira, A. S. C. (2018). Fat deposition, fatty acid composition, and its relationship with meat quality and human health. In M. S. Arshad (Ed.), Meat Science and Nutrition (Chap. 2, pp. 17-37). London: IntechOpen. http://dx.doi.org/10.5772/ intechopen.77994.

McClure, M. C., Ramey, H. R., Rolf, M. M., McKay, S. D., Decker, J. E., Chapple, R. H., Kim, J. W., Taxis, T. M., Weaber, R. L., Schnabel, R. D., \& Taylor, J. F. (2012). Genome-wide association analysis for quantitative trait loci influencing Warner-Bratzler shear force in five taurine cattle breeds. Animal Genetics, 43(6), 662-673. http:// dx.doi.org/10.1111/j.1365-2052.2012.02323.x. PMid:22497286.

National Research Council - NRC. (2000). Nutrient requirements of beef cattle (7th ed.). Washington: National Academy Press.

Nuernberg, K., Dannenberger, D., Ender, K., \& Nuernberg, G. (2007). Comparison of different methylation methods for the analysis of conjugated linoleic acid isomers by silverion HPLC in beef lipids. Journal of Agricultural and Food Chemistry, 55(3), 598-602. http:// dx.doi.org/10.1021/jf061865k. PMid:17263447.

Oliveira, E. A., Sampaio, A. A. M., Henrique, W., Pivaro, T. M., Rosa, B. L., Fernandes, A. R. M., \& Andrade, A. T. (2012). Quality traits and lipid composition of meat from Nellore young bulls fed with different oils either protected or unprotected from rumen degradation. Meat Science, 90(1), 28-35. http://dx.doi.org/10.1016/j.meatsci.2011.05.024. PMid:21680103.

Oliveira, R. L., Neto, S. G., Lima, F. H. S., Medeiros, A. N., Bezerra, L. R., Pereira, E. S., Bagaldo, A. R., Pellegrini, C. B., \& Correia, B. R. (2016). Composition and fatty acid profile of milk from cows supplemented with pressed oilseed cake. Animal Science Journal, 87(10), 1225-1232. http://dx.doi.org/10.1111/asj.12571. PMid:26707702.

Paim, T. P., Viana, P., Tilburg, M. F., Moura, A. A., Souza, J. R., McManus, C., Abdalla, A. L., \& Louvandini, H. (2019). Feeding effects of cottonseed and its co-products on the meat proteome from ram lambs. Scientia Agrícola, 76(6), 463-472. http://dx.doi. org/10.1590/1678-992x-2018-0072.

Park, S. J., Beak, S., Jung, D. J. S., Kim, S. Y., Jeong, I. H., Piao, M. Y., Kang, H. J., Fassah, D. M., Na, S. W., Yoo, S. P., \& Baik, M. (2018). Genetic, management, and nutritional factors affecting intramuscular fat deposition in beef cattle - a review. Asian-Australasian Journal of Animal Sciences, 31(7), 1043-1061. http://dx.doi.org/10.5713/ ajas.18.0310. PMid:29879830.

Rhee, K. S. (2000). Fatty acids in meats and meat products. In C. K. Chow (Ed.), Fatty acids in foods and their health implications (Chap. 2, pp. 47-66). New York: Marcel Dekker.

Saldanha, T., Mazalli, M. R., \& Bragagnolo, N. (2004). Avaliação comparativa entre dois métodos para determinação do colesterol em 
carnes e leite. Food Science and Technology, 24(1), 109-113. http:// dx.doi.org/10.1590/S0101-20612004000100020.

Santos-Silva, J., Bessa, R. J., \& Santos-Silva, F. (2002). Effect of genotype, feeding system and slaughter weight on the quality of light lambs. Livestock Production Science, 77(2-3), 187-194. http://dx.doi. org/10.1016/S0301-6226(02)00059-3.

Scollan, N., Hocquette, J. F., Nuernberg, K., Dannenberger, D., Richardson, I., \& Moloney, A. (2006). Innovations in beef production systems that enhance the nutritional and health value of beef lipids and their relationship with meat quality. Meat Science, 74(1), 17-33. http://dx.doi.org/10.1016/j.meatsci.2006.05.002. PMid:22062713.

Ulbricht, T. L. V., \& Southgate, D. A. T. (1991). Coronary heart disease: seven dietary factors. The Lancet, 338(8773), 985-992. http://dx.doi. org/10.1016/0140-6736(91)91846-M. PMid:1681350.

Vahmani, P., Ponnampalam, E. N., Kraft, J., Mapiye, C., Bermingham, E. N., Watkins, P. J., Proctor, S. D., \& Dugan, M. E. R. (2020).
Bioactivity and health effects of ruminant meat lipids. Invited review. Meat Science, 165, 108114. http://dx.doi.org/10.1016/j. meatsci.2020.108114. PMid:32272342.

Valadares, S. C. Fo, Lopes, S. A., Machado, P. A. S., Chizzotti, M. L., Amaral, H. F., Magalhães, K. A., Rocha, V. R. Jr, \& Capelle, E. R. (2020). Tabelas brasileiras de composição de alimentos para bovinos. Viçosa: Editora UFV. Retrieved from https://www.cqbal.com.br/\#!/

Zambiazi, R. C., Przybylsk, R. I., Zambiazi, M. W., \& Mendonça, C. B. (2007). Fatty acid composition of vegetable oils and fats. Boletim do Centro de Pesquisa e Processamento de Alimentos, 25(1), 111-120.

Zeraatkar, D., Johnston, B. C., Bartoszko, J., Cheung, K., Bala, M. M., Valli, C., Rabassa, M., Sit, D., Milio, K., Sadeghirad, B., Agarwal, A., Zea, A. M., Lee, Y., Han, M. A., Vernooij, R. W. M., Alonso-Coello, P., Guyatt, G. H., \& El Dib, R. (2019). Effect of lower versus higher red meat intake on cardiometabolic and cancer outcomes: a systematic review of randomized trials. Annals of Internal Medicine, 171(10), 721-731. http://dx.doi.org/10.7326/M19-0622. PMid:31569236. 